Int. J. Electrochem. Sci., 15(2020) $3704-3714$

\title{
Batch and Flow-Injection Analysis of Lauryl Sulfate in Industrial Products and Wastes Using Membrane Sensors Based on Methyltrioctylammonium Chloride
}

\author{
Hisham S. M. Abd-Rabboh ${ }^{1,2, *}$ \\ ${ }^{1}$ Chemistry Department, Faculty of Science, King Khalid University, PO Box 9004, Abha 61413, \\ Saudi Arabia \\ ${ }^{2}$ Department of Chemistry, Faculty of Science, Ain Shams University, Abbassia, Cairo 11566, Egypt \\ *E-mail: hasalah@ hotmail.com
}

doi: $10.20964 / 2020.05 .18$

Received: 3 January 2020 / Accepted: 23 February 2020 / Published: 10 April 2020

\begin{abstract}
Liquid polymeric membrane sensors based on the hydrophobic cationic surfactant methyltrioctayammonium chloride (MTOAC) are described herein for batch and flow injection analysis of sodium lauryl sulfate (SLS) surfactant. PVC-based membrane sensors were prepared using different plasticizers in two different electrode designs: conventional polymeric membrane discs for batch measurements and flow-through half cell module for flow-injection analysis. o-nitrophenyloctyl ether plasticized sensors exhibited the most distinguished response characteristics among other sensors in $10^{-2} \mathrm{M}$ phosphate buffer solution at $\mathrm{pH}=7$, with a lower detection limit of $3.97 \times 10^{-7} \mathrm{M}$, a linear dynamic range of $9.33 \times 10^{-7}-5.31 \times 10^{-3} \mathrm{M}$, a slope of $-59.4 \mathrm{mV} /$ concentration decade, a correlation coefficient of 0.999 and a response time of $60 \mathrm{~s}$. The sensors were selective towards SLS over other common anions and exhibited a long life time (more than 2.5 months) with a constant detection limit, an enhanced linear range, and a slight increase in its slope. The fabricated sensors were efficiently used in the determination of SLS concentrations in a wide range of samples including powder detergents, tooth paste, liquid hand wash, and shampoo, and wastewater.
\end{abstract}

Keywords:Potentiometry; flow-injection analysis; ion-selective electrode; sodium lauryl sulfate; surfactant analysis

\section{$\underline{\text { FULL TEXT }}$}

(C) 2020 The Authors. Published by ESG (www.electrochemsci.org). This article is an open access article distributed under the terms and conditions of the Creative Commons Attribution license (http://creativecommons.org/licenses/by/4.0/). 